\title{
Future danger posed by fungi in the Ophiostomatales when encountering new hosts
}

\author{
${ }^{1}$ Tendai Musvuugwa \\ ${ }^{2}$ Léanne L. Dreyer \\ ${ }^{3}$ Francois Roets
}

\begin{abstract}
${ }^{1}$ Department of Botany and Zoology, Stellenbosch University, Private Bag X1, Stellenbosch, 7600, South Africa ${ }^{2}$ Department of Botany and Zoology, Stellenbosch University, Private Bag X1, Stellenbosch, 7600, South Africa and DST/NRF Centre of Excellence in Tree Health Biotechnology (CTHB), Forestry and Agricultural Biotechnology Institute (FABI), University of Pretoria, Private Bag X20, Hatfield, Pretoria, 0028, South Africa ${ }^{3}$ Department of Conservation Ecology and Entomology, Stellenbosch University, Private Bag X1, Stellenbosch, 7600, South Africa and DST/NRF Centre of Excellence in Tree Health Biotechnology (CTHB), Forestry and Agricultural Biotechnology Institute (FABI), University of Pretoria, Private Bag X20, Hatfield, Pretoria, 0028, South Africa
\end{abstract}

Corresponding author Francois Roets, email address: fr@sun.ac.za, telephone: +2721 808 2635, fax: $+27218084821$

\begin{abstract}
The Ophiostomatales contain pathogens that threaten forests world-wide. Global trade increases encounters with new hosts, with potential devastating consequences. We assessed the danger posed by the movement of Ophiostomatales between different host trees in South Africa. We tested the pathogenicity of five fungal species from native South African trees, and three from exotic trees, on various native and exotic trees. To evaluate the potential of fungi to move to new hosts, we investigated the strength of their associations with arthropod vectors. Results indicate that many fungal species are pathogens of newly encountered and distantly-related hosts. Encounters of pathogens with new hosts are less likely when host plants are distantly related, and outside the host range of boring beetle vectors, which also
\end{abstract}


reduces the chances of vectoring by phoretic mite associates. However, pathogens associated with numerous mite species and wounds are more likely to encounter new hosts and pose future threats.

Key words: Afromontane forest, Graphilbum, Ophiostoma, Raffaelea, Scolytinae

\section{Introduction}

Ophiostomatoid fungi (Ophiostomatales) are best known as associates of beetles (Coleoptera: Curculionidae, Scolytinae) (Harrington, 1987; Jacobs and Wingfield, 2001; Jacobs et al. 2003). In many cases these associations are mutualistic, whereby the fungi are believed to provide nutritional benefits to the beetles (Klepzig et al. 2001) and the beetles transport fungi to new host plants (Paine et al. 1997; Six, 2003). However, some members are not associated with Scolytinae beetles and have been isolated from diverse habitats including wounds on trees, soil, other fungi and wood of dead trees (de Meyer et al. 2008; Kamgan et al. 2008; Cruywagen et al. 2010; Musvuugwa, 2014) and may be associated with many other arthropods such as Cerambycidae beetles, mites and Nitidulide beetles (Bridges and Moser, 1983; Moser, 1985; Jacobs and Wingfield, 2001; Klepzig et al. 2001; Lombardero et al. 2003; Roets et al. 2007). In fact, all members of the Ophiostomatales are specifically adapted for arthropod mediated spore dispersal as they produce sticky spores at the tips of elongated structures that are not easily distributed via other mechanisms (Malloch and Blackwell, 1993). The dispersal biology of the non-Scolytinae associated taxa is far less well-studied, but it is becoming clear that mites may be central to the dispersal of many of these. For example, mites are known to have associations with Ophiostomatales in environments such as Protea flower heads (Roets et al. 2007) and wounds on trees (Musvuugwa, 2014). 
Mites also play a very important role in the dispersal of some Ophiostomatales associated with Scolytinae beetles (Hofstetter et al. 2013). For example, Tarsonemus ips and T. krantzii are associated with the southern pine beetle, Dendroctonus frontalis (Klepzig et al. 2001; Price et al. 1992; Smiley and Moser, 1974) and both are responsible for vectoring spores of Ophiostoma minus (Klepzig et al. 2001). As in the case of some beetles that have specialised spore carrying structures (mycangia), mites may have mutualistic relationships with the fungi they carry and may also carry fungi in special structures (sporothecae) (Bridges and Moser, 1983; Moser et al. 1995). These relationships can be just as specialised as with the beetles, as some mites feed and reproduce exclusively on their fungal associates (Klepzig and Six, 2004; Roets et al. 2007).

Many Ophiostomatales are well-known pathogens of both native and exotic trees world-wide (Klepzig et al. 2001; Six and Wingfield, 2011). They have caused major financial losses in many forestry and agricultural sectors. For example, Raffaelea quercivora and its associated beetle, Platypus quercivorus, were responsible for the catastrophic mass mortality and dieback of Japanese oak trees (Kubono and Ito, 2002). Numerous taxa can also cause substantial financial losses as they contribute to blue-staining of conifer timber (Harrington, 2005). The blue-stain fungi Ophiostoma minus and O. pluriannulatum are, for example, known to reduce the commercial value of timber (Harrington, 2005).

In many cases, accidental introductions of fungal species and their vectors into new environments can cause disease outbreaks with serious consequences (Brasier, 2008; Loo, 2009). These accidental introductions happen due to increased globalisation of trade in plants, and inadequate international plant biosecurity protocols (Brasier and Webber, 2010). In some cases the introduced fungi can move from one host species to another, often aided by their 
vectors (Wingfield, 2003; Woolhouse et al. 2005). The limited resistance offered by the new hosts may lead to excessive aggressiveness by the introduced pathogen (Brasier and Buck, 2001). Well-known examples include the Dutch elm disease epidemic that was responsible for the catastrophic losses of American elm trees, Ulmus americana (Brasier and Buck, 2001; Heybroek, 1993; Lamb, 1979). This was due to the introduction of O. ulmi and O. novo-ulmi, along with their vector the European elm bark beetle (Scolytus multistriatus) (Webber, 1990), from their European host, through the importation of infested elm timber to America (Brasier, 1990; Peace, 1960). Raffaelea lauricola along with its invasive exotic vector beetle, the red bay ambrosia beetle Xyleborus glabratus, were introduced into southeastern USA from Asia on solid wood packing material (Harrington et al. 2008). The fungus moved onto native members of the Lauraceae, including avocado trees, causing Laurel wilt disease that often kill these new hosts (Harrington et al. 2008). Even when introduced fungi do not necessarily kill trees, these may degrade tree defence systems and contribute to successful bark beetle attack which indirectly increases tree mortality (DiGuistini et al. 2011; Hammerbacker et al. 2013).

Like other ecosystems around the world, the Cape Floristic Region (CFR) of South Africa is under increased threat from anthropogenic influences. Numerous economically important exotic plant species and their associated organisms have been introduced and are now invasive within natural CFR habitats. This is especially true for some of the most important South African plantation forestry taxa such as Acacia mearnsii, Eucalyptus spp. and Pinus spp. (Moran and Hoffman, 2012). These taxa invaded vast areas of natural CFR vegetation and are ideal organisms to study the possibility and consequences of fungi moving to newly encountered hosts, as they are in close contact with many native tree taxa. The aim of this study was firstly to identify possible consequences when members of the Ophiostomatales move to newly encountered hosts by testing their pathogenicity on various usual hosts and 
possible newly encountered hosts. The likelihood that fungi would move to newly encountered hosts was assessed by identifying known host range of the fungi, and also by testing the specificity of various mites towards their natural beetle vectors and those that they would not normally associate with.

\section{Materials and methods}

\section{Selection of study organisms}

We focussed on three important plantation forestry tree species (Acacia mearnsii, Eucalyptus grandis and Pinus radiata) that are invasive in natural CFR vegetation (Moran and Hoffman, 2012). These taxa often grow in dense stands and are often in close proximity to native trees found in the Afromontane forest patches scattered throughout the CFR. Recent surveys of members of the Ophiostomatales from the CFR revealed that there are many undescribed or newly described taxa present on native trees within Afromontane forests (Musvuugwa, 2014, Musvuugwa et al. 2015). Some of these appeared to be host specific, while others had very wide host ranges. These surveys also revealed the presence of members of the Ophiostomatales on exotic species. Numerous taxa were associated with sub-cortical beetles, their phoretic mites and/or mites from wounds on storm damaged trees (Musvuugwa, 2014). For the present study we selected fungal species that likely differ in their dispersal ecology in order to assess the possible consequences and likelihood of moving to new hosts (Table 1).

Our study was prompted by recent problems caused by a native ophiostomatoid fungus (Microascales: Ceratocystis albifundus) on exotic A. mearnsii plantation trees (De Beer, 1994; Roux and Wingfield, 1997) and then our own recent collection of an exotic phoretic mite (Dendrolaelaps quadrisetus) on both a non-native sub-cortical beetle (Orthotomicus erosus) from $P$. radiata and a native species (Lanurgus sp. 1) from a native host, Olea 
Table 1. Study organisms and their associated host tree species (from Musvuugwa, 2014; Musvuugwa et al. 2015) in the CFR that were used in this study. CMW = culture collection of the Forestry and Agricultural Biotechnology Institute (FABI) at the University of Pretoria, South Africa.

\begin{tabular}{|c|c|c|c|}
\hline Fungal species and isolates & Host trees & Beetle associates & Mite associates \\
\hline $\begin{array}{l}\text { Ceratocystiopsis } \text { sp. } 1 \\
\text { (CMW40346, CMW40347, } \\
\text { CMW40348) }\end{array}$ & Pinus radiata & Orthotomicus erosus & $\begin{array}{l}\text { Dendrolaelaps } \\
\text { quadrisetus }\end{array}$ \\
\hline $\begin{array}{l}\text { Graphilbum roseus } \\
\text { (CMW40349, CMW40350, } \\
\text { CMW40351) }\end{array}$ & $\begin{array}{l}\text { Curtisia dentata, Halleria lucida, Olea } \\
\text { capensis ssp. Macrocarpa, } \\
\text { Pterocelastrus tricuspidatus, } \\
\text { Trichocladus crinitus }\end{array}$ & None known & $\begin{array}{l}\text { Lasioseius } \mathrm{sp} .1 \\
\text { Mesosigmata sp. } 1 \\
\text { Oribatida sp. } 2\end{array}$ \\
\hline $\begin{array}{l}\text { Ophiostoma ips } \\
\text { (CMW40322, CMW40337, } \\
\text { CMW40338) }\end{array}$ & Pinus radiata & Orthotomicus erosus & $\begin{array}{l}\text { Dendrolaelaps } \\
\text { quadrisetus }\end{array}$ \\
\hline $\begin{array}{l}\text { Ophiostoma pluriannulatum- } \\
\text { like } \\
\text { (CMW40333, CMW40334, } \\
\text { CMW40335) }\end{array}$ & $\begin{array}{l}\text { Acacia mearnsii, Curtisia dentata, Olea } \\
\text { capensis, Pterocelastrus sp., Rapanea } \\
\text { melanophloeos }\end{array}$ & None known & $\begin{array}{l}\text { Acaridae sp. } 1 \\
\text { Mesostigmata sp.1 } \\
\text { Uroobovella } \mathrm{sp} .1\end{array}$ \\
\hline $\begin{array}{l}\text { Raffaelea rapaneae } \\
\text { (CMW40357, CMW40358, } \\
\text { CMW40359) }\end{array}$ & Rapanea melanophloeos & Platypodinae sp. 1 & None known \\
\hline $\begin{array}{l}\text { Sporothrix pallida } \\
\text { (CMW40330, CMW40331, } \\
\text { CMW40332) }\end{array}$ & Olea capensis ssp. macrocarpa & $\begin{array}{l}\text { Ctonoxylon sp. } 1 \\
\text { Lanurgus sp. } 1 \text {, }\end{array}$ & None known \\
\hline $\begin{array}{l}\text { Sporothrix rapaneae } \\
\text { (CMW40367, CMW40368, } \\
\text { CMW40369) }\end{array}$ & Rapanea melanophloeos & None known & None known \\
\hline $\begin{array}{l}\text { Sporothrix sp. } 1 \\
\text { (CMW40378, CMW40379, } \\
\text { CMW40380) }\end{array}$ & Pinus radiata & Orthotomicus erosus & $\begin{array}{l}\text { Dendrolaelaps } \\
\text { quadrisetus }\end{array}$ \\
\hline
\end{tabular}

capensis ssp. macrocarpa (Musvuugwa, 2014). Dendrolaelaps quadrisetus was found to be associated with three exotic Ophiostomatales species (Ophiostoma ips, Sporothrix sp. 1 and Ceratocystiopsis sp. 1) on $P$. radiata (all associated with exclusively pine-associated bark- 
beetles) and Sporothrix pallida that was isolated from Olea capensis spp. macrocarpa (Musvuugwa, 2014). Sporothrix pallida was also isolated from the beetle Lanurgus sp. 1, the native phoretic partner of D. quadrisetus (Musvuugwa, 2014). This led us to suspect that the fungi associated with this mite can move between host plants and that the mite is not very specific towards its vectors. Sporothrix pallida was also found to be associated with the native subcortical beetle Ctonoxylon sp. 1 (Musvuugwa, 2014) and is known from many other environments including water sediments, soil, the sporophore of a slime-mould (De Meyer et al. 2008) and from a corneal ulcer of a human patient (Morrison et al. 2013). This fungus is, therefore, not very host and/or vector specific and may easily move from one environment to the next.

Ophiostoma pluriannulatum and Graphilbum proposed sp. nov. roseus (G. roseus from hereon, Musvuugwa, 2014) are associated with numerous mite taxa (none known to be phoretic) and with wounds on diverse native trees (Musvuugwa, 2014). These species are expected to easily move between various hosts using these mites as primary vectors. These fungi have, however, not yet been isolated from wounds on exotic trees, which raises the question of whether they are able to grow on these hosts. Sporothrix proposed sp. nov. rapaneae (S. rapaneae from hereon, Musvuugwa, 2014) is currently only known from wounds on one host tree species (Rapanea melanophloes). Its associated organisms are unknown, but most likely include various mites. Like with $O$. pluriannulatum and G. roseus, it may therefore be able to move easily between different hosts. Raffaelea rapaneae is an ambrosial fungus associated with a Platypodinae beetle (Musvuugwa et al. 2015). The nature of this association is probably very specific (Henriques et al. 2006) and the dispersal of this species to tree taxa other than $R$. melanophloeos is therefore less likely. 


\section{Growth studies}

The growth of various members of the Ophiostomatales from the CFR was tested by inoculating them onto various hosts including those that they are not usually associated with (Table 1). Three native tree species (Curtisia dentata, Olea capensis ssp. macrocarpa and Rapanea melanophloeos and the three exotic tree species (A. mearnsii, E. grandis, $P$. radiata) were used in these experiments. Our aim was to determine how host specific these fungi are (i.e. can they grow on possible newly encountered hosts) and if so, whether they could be pathogenic to these newly encountered hosts. Three isolates of each of the eight fungal species assessed were used for inoculation experiments. A cork borer ( $8 \mathrm{~mm}$ diameter) was used to make wounds on branches ( $c a .15 \mathrm{~mm}$ diameter) of trees by opening the cambium. Mycelial plugs of the same size were taken from edges of actively growing fungal colonies (1-2 weeks old) on Malt Extract Agar (MEA; Biolab, Midrand, South Africa) and inserted onto the wounds with mycelium facing the cambium. The experiment was replicated five times for each of the three isolates per fungal species tested on each of the six tree species evaluated. Only a single inoculation was done per individual tree, whereafter wounds were sealed with masking tape to prevent desiccation. As a control, wounds were inoculated with sterile MEA plugs. After 6 weeks all inoculated branches were removed and lengths of lesions resulting from the inoculations were measured. Re-isolations were made from the front of the lesions in order to confirm the identity of the lesion-causing fungi. Re-isolations were made by surface sterilising wounds with $70 \%$ ethanol and removing pieces of inner wood $\left(2 \mathrm{~mm}^{2}\right)$. These were placed on MEA in Petri dishes and incubated in the dark at room temperature $\left(\mathrm{ca} \cdot 23^{\circ} \mathrm{C}\right)$. Pure cultures of the fungi were identified based on morphological characters. 
Differences in mean lesion length caused by the various fungal isolates and that of the control on each of the host trees were determined using One-way ANOVA in Statistica 11 (Statsoft Corporation, USA). The data were tested for normality using a Shapiro-Wilk test. Data were normally distributed and no transformation was required before analyses. Means were separated by a Dunnett Post-hoc test in Statistica 11. We assumed that when the mean lesion length for an isolate was higher than the upper standard error of the control, the fungal isolate was able to grow on that particular host. We further assumed that a particular isolate was pathogenic to the host when its mean lesion length was statistically longer than that of the control.

\section{Ability of phoretic mites to distinguish between vector and non-vector beetles}

To determine the level of specificity between phoretic mites and their beetle vectors, we tested the ability of mites to distinguish between vector and non-vector beetles. Three mites that are known to be vectored by beetles were selected based on availability. These were Dendrolaelaps quadrisetus known from bark beetles on Pinus spp. and Olea capensis ssp. macrocarpa (Table 1), and two species (Proctalaelaps vandenbergi and Trichouropoda sp. 3) that are only known as associates of native beetles (Genuchus hottentottus and Trichostetha fascicularis, both in the Scarabaeidae, collected from Protea spp. (Roets et al. 2009). Dendrolaelaps quadrisetus is a predatory mite that feeds on eggs and larvae of its phoront beetle (Kinn, 1967) and also in some cases feeds on nematodes, but it often carries spores of members of the Ophiostomatales (Cardoza et al. 2008; Musvuugwa, 2014). Trichauropoda sp. 3 has a close mutualistic association with members of the Ophiostomatales (Roets et al 2007), while Proctolaelaps vandenbergi is a pollen and nectar feeder that also often carries spores of the Ophiostomatales (Roets et al. 2007). To account for possible learned behavior (or experience), mites used in experiments were not collected from vector beetles. Rather, 
individuals of D. quadrisetus were collected from under the bark of O. capensis ssp. macrocarpa, while those of $P$. vandenbergi and Trichauropoda sp. 3 were collected from Protea infructescences. Each mite individual was only used once in any experiment.

Mites were allowed to associate with three other beetle taxa besides their natural vector. Dendrolaelaps quadrisetus was allowed to associate with one of its normal vectors (Lanurgus sp. 1 from host $O$. capensis ssp. macrocarpa) and the non-usual vectors Lasioderma serricorne (Anobiidae) (from contaminated dried Gonimbrasia belina used in stews in southern Africa), Cryphalinae sp. 1 (from Virgilia oroboides) and Ctonoxylon sp. 2 (from Olea sp.). Lasioderma serricorne was chosen as this beetle has no known mite associates and is not found in natural areas in the CFR. Both P. vandenbergi and Trichauropoda sp. 3 were allowed to associate with their normal vector $(G$. hottentottus) and the non-usual vectors Lanurgus sp. 1, L. serricorne and Cryphalinae sp. 1. Vector studies were carried out testing two different scenarios, a no-choice experiment and a choice experiment.

In the no-choice experiments, five individuals of each of the three tested mite species were placed in a Petri dish (60 $\mathrm{mm}$ diameter) containing a single individual of the beetle species tested as possible associate (as outlined above). The experiment was replicated five times for each of the tree mite species on each of the different beetle species tested. After $24 \mathrm{hr}$ the total number of mites found on the individual beetles was counted. In the choice experiment, test arenas were again set up in Petri dishes (60 $\mathrm{mm}$ diameter). One individual of each of the four beetle species tested for association with a particular mite species (as outlined above) was placed in the dish. Hereafter 20 individuals of the particular mite species assessed were added to the arena. The experiment was replicated five times for each of the three mite species tested. The total number of mites found on each individual beetle per arena was again 
recorded after $24 \mathrm{hr}$. Differences in medians for number of mites that associated with the various beetles were determined using Kruskal-Wallis ANOVA in Statistica 11.

\section{Results}

Growth studies

After 6 weeks all fungal species had at least two isolates that were able to grow on $P$. radiata (Fig. 1A) and there were no differences between mean lesion lengths caused by the various fungal isolates and that of the control ( $\mathrm{df}=24 ; \mathrm{f}=1.4 ; \mathrm{p}=0.12)$ (Fig. 1A). Therefore, according to our definition, none of the fungal species used proved to be pathogenic to $P$. radiata. All fungal taxa tested were able to grow on $A$. mearnsii, except for the pine associated $O$. ips (Fig. 1B). Mean lesion length varied signifficantly on this host $(\mathrm{df}=24 ; \mathrm{f}=$ $6.8 ; \mathrm{p}<0.001$ ) with $G$. roseus and $O$. pluriannulatum, producing distinct lesions compared to the control (Fig. 1B). Four of the fungal taxa tested were not able to grow on E. grandis including S. rapaneae, S. pallida, O. pluriannulatum and Ceratocystiopsis sp. 1 (Fig. 1C). However, mean lesion length varied significantly on this host $(\mathrm{df}=24 ; \mathrm{f}=3.7$; $\mathrm{p}<0.001$ ), with the native fungi $R$. rapaneae and $G$. roseus, and the non-native Sporothrix sp. 1 and $O$. ips causing significantly larger lesions than the controls (Fig. 1C).

All isolates of all tested fungal species were able to grow on $R$. melanophloeos (Fig 1D) and mean lesion lengths varied significantly $(\mathrm{df}=24 ; \mathrm{f}=4.1 ; \mathrm{p}<0.001)$. Taxa that produced significantly larger lesions than the control on this species included S. rapaneae, G. roseus, $S$. pallida, O. pluriannulatum and the non-native O. ips (Fig 1D). Very few isolates tested were able to grow on $O$. capensis ssp. macrocarpa and there were no differences in mean lesion lengths caused by the various fungal isolates and that of the control $(\mathrm{df}=24 ; \mathrm{f}=0.81 ; \mathrm{p}=$ 0.72) (Fig. 1E). All fungal species tested on C. dentata were able to grow on this tree (Fig. 


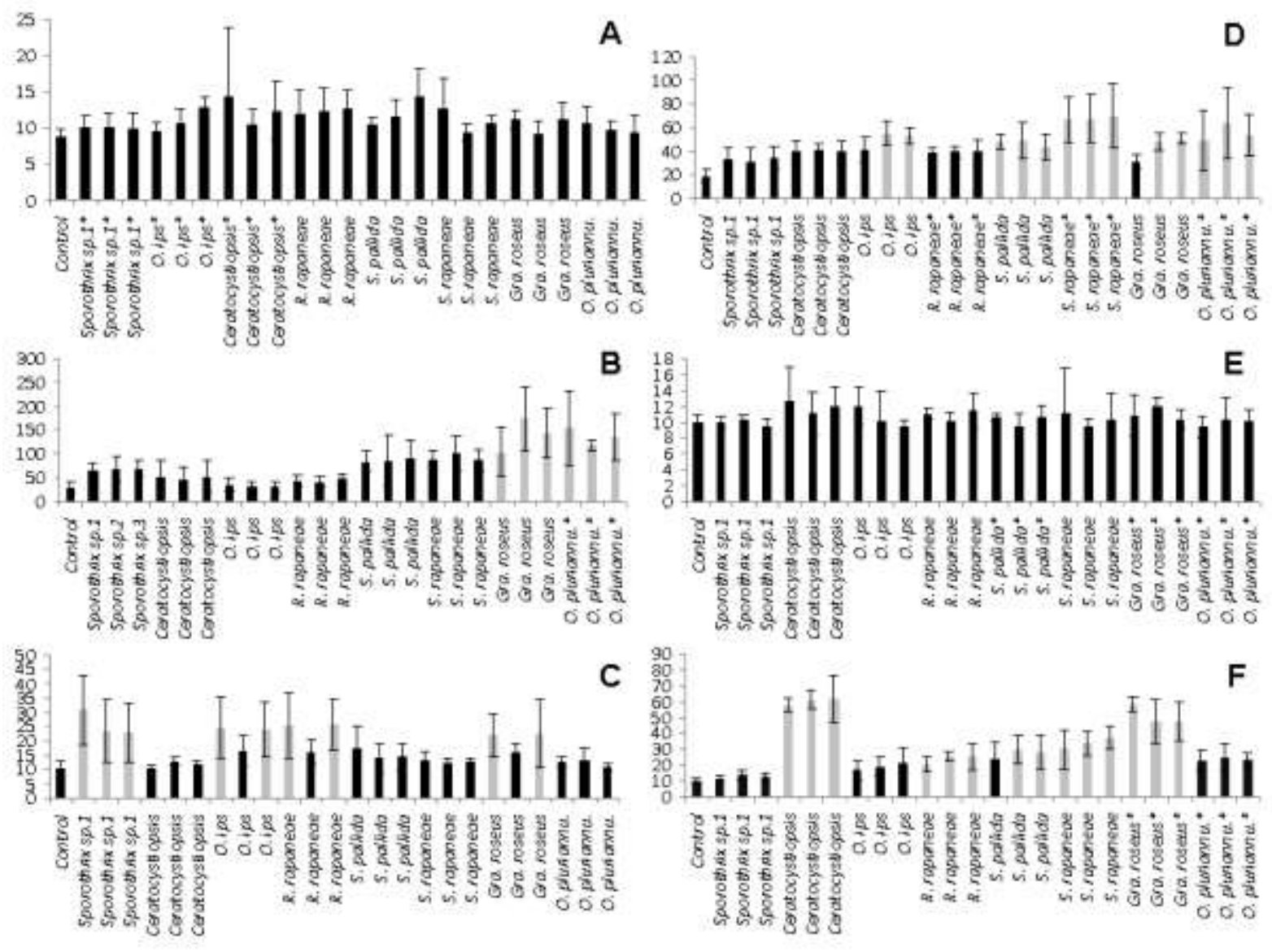

Figure 1. Mean lesion lengths (+/- SE) caused by various members of the Ophiostomatales on the non-native host tree taxa (A) Pinus radiata, (B) Acacia mearnsii and (C) Eucalyptus grandis and the native host tree species (D) Rapanea melanophloeos, (E) Olea capensis ssp. macrocarpa and (F) Curtisia dentata. Isolates indicated by grey bars differed significantly from the controls. The first three fungal species on the graphs (Sporothrix sp. 1, Ophiostoma ips and Ceratocystiopsis sp.) are presumably exotic to South Africa while the rest are likely native to the country. All but the last three fungal species (Sporothrix rapaneae, Graphilbum roseus, Ophiostoma pliriannulatum) are known as Scolytinae beetle associates. These three taxa are known only from wounds on trees. Species indicated by asterisks (*) are known from the particular host depicted in the graph.

1F). Results from the One-way ANOVA indicated significant variance in mean lesion length $(\mathrm{df}=24 ; \mathrm{f}=20.2 ; \mathrm{p}<0.001)$ with five fungal species producing significantly longer lesions than controls on $C$. dentata. These were $S$. rapaneae, $R$. rapaneae, G. roseus, $S$. pallida and the non-native Ceratocystiopsis sp.1 (Fig. 1F).

Ability of mites to distinguish between vector and non-vector beetles

In the no-choice experiments, all the phoretic mite species only associated with their natural vector beetles. Dendrolaelaps quadrisetus only associated with its vector beetle, Lanurgus sp. 
$1(\mathrm{df}=3, \mathrm{H}=18.5547, \mathrm{p}<0.001)$, Trichouropoda $\mathrm{sp} .3$ only chose to climb onto their native Protea beetle vector, G. hottentottus ( $\mathrm{df}=3, \mathrm{H}=18.6275, \mathrm{p}<0.001$ ), while the Proteaassociated $P$. vandenbergi were also specific to their native vector beetle, G. hottentottus (df $=3, \mathrm{H}=18.6031, \mathrm{p}<0.001)$. Similarly, in the choice experiments, all the phoretic mite species only associated with their natural vector beetles. The Olea-associated D. quadrisetus only associated with Lanurgus sp. 1 ( $\mathrm{df}=3, \mathrm{H}=18.5547, \mathrm{p}<0.001)$, Trichouropoda $\mathrm{sp} .3$ only associated with their natural phoront, G. hottentottus $(\mathrm{df}=3, \mathrm{H}=18.7500, \mathrm{p}<0.001$ ), and $P$. vandenbergi only climbed onto Genuchus hottentottus $(\mathrm{df}=3, \mathrm{H}=18.6275, \mathrm{p}<$ $0.001)$.

\section{Discussion}

Results from this study reveal the possible effects and dangers posed by various members of the Ophiostomatales when they encounter new host trees in the CFR. This is important, as it has been shown that when fungal species encounter new environments, they can cause disease outbreaks with serious consequences (Brasier, 2008; Loo, 2009). When they move from one host species to another, usually through their vectors (Wingfield, 2003; Woolhouse et al. 2005), they can experience limited resistance by the new hosts, which can lead to excessive aggressiveness by the introduced pathogen (Brasier and Buck, 2001). At least two fungal species were able to grow on each of the host trees they were tested on and at least two fungal species were pathogenic on all the tree species they were tested on except on $O$. capensis ssp. macrocarpa and $P$. radiata. Importantly these hosts do not necessarily have to be closely related. This implies that future dangers posed by movement of Ophiostomatales species between native and non-native hosts cannot be readily predicted. 
According to the Food and Agriculture Forest Organisation of the United Nations (FAO; www.fao.org/forestry/pests) a disease can be defined as a condition caused by living organisms or environmental changes that impair the normal functions of another living organism. A pathogen is a micro-organism (such as a fungus) that causes a disease. Although at least two fungal species were identified as pathogenic on most tree species, it is important to note that the definition of pathogenicity in this paper refers to an isolate that caused a lesion significantly larger than the wound only controls. We, therefore, assume that that a particular isolate could cause an infection and may interfere with the normal functioning of the plant if left untreated for extended periods of time. Plant defences may, however, stop these infections from causing harm in the future and we may, therefore, have overestimated pathogenicity here. In contrast, some isolates that grow slowly may still prove to cause longer lesions and be classified as pathogenic given more time to develop. However, many studies rely on this method of testing pathogenicity (e.g. Chen et al. 2013; Machingambi et al. 2015) as monitoring disease development after inoculation will have to be carried out over extended periods of time on long-lived organisms such as trees to verify whether the fungi could impair normal functioning.

Also presented in this study is the relationship between phoretic mites, their natural beetle vectors and other beetles they are not likely to encounter in the field. Results showed that there is a high level of specificity between the mites and their natural vectors, at least when the beetle taxa are phylogenetically distantly related. However, it is well known that mites tend to move between vector beetles, especially when these occur on the same hosts. In fact, commonly a single mite species is often phoretic on many species of bark and other beetles including the predators and competitors of Scolytinae (Hofstetter et al. 2013). These predators may provide phoretic mites opportunities to switch between distantly related plant 
hosts in the search for food and it is, therefore, possible that the fungi studied here could encounter new hosts via insect taxa not evaluated in the current study. However, Ophiostomatales species typically do not rely only on mites for vectoring, but rather mites complement their movement via beetles (e.g. Hofstetter et al. 2013). Fungal species associated with boring beetles are not likely to easily encounter new, distantly related, hosts as the beetles tend to be specific towards certain hosts at the plant family or plant genus level (Smiley and Moser, 1974; Price et al. 1992; Klepzig et al. 2001; Walter et al. 2010; Hofstetter et al. 2013). However, chances of encountering new hosts by boring-beetle associated Ophiostomatales may be enhanced if the hosts are phylogenetically closely related. For example in the case of the Dutch elm disease, the causative agents $O$. ulmi and $O$. novo-ulmi together with their vector, the European elm bark beetle, successfully invaded a new host, the American elm tree, which is closely related to their natural host, the European elm tree (Peace, 1960; Lamb, 1979; Brasier, 1990; Webber, 1990; Heybroek, 1993; Brasier and Buck, 2001). Similarly Raffaelela lauricola along with its vector beetle Xyleborus glabratus that were introduced into the southeastern USA successfully moved onto native species that belong to the same family (Lauraceae) as that of its natural Persea borbonia host. (Harrington et al. 2008). Importantly, native bark beetles commonly acquire introduced Ophiostomatales species especially when the hosts are fairly closely related (e.g. Jacobs et al. 2004). Some of the beetle-associated fungi tested in this study were from tree species that are relatively closely related to tree species that are of economic and ecological importance in the CFR. The phylogenetic relatedness of these hosts may enhance their chances of getting infected by beetle-associated Ophiostomatales. For example, Pinus radiata is fairly closely related to some ecologically and economically important native trees such as Podocarpus species and Widringtonia species in the order Pinales. Olea capensis ssp. macrocarpa is closely related to the economically very important domestic olive tree (O. europea). It is 
possible that the beetle-associated Ophiostomatales from $P$. radiata and $O$. capensis ssp. macrocarpa can encounter these close relatives where these grow in close proximity in the CFR and cause majour damage. There is, therefore, a need to assess the pathogenicity of the fungi tested in this study on other, more closely related tree taxa in future studies.

None of the fungi tested was pathogenic on $P$. radiata or $O$. capensis ssp. macrocarpa. It is possible that these tree species are highly resistant to attack by many pathogens. $O$. capensis ssp. macrocarpa has never before been recorded to be attacked by, or associated with, any pathogenic fungus. However, major losses of $P$. radiata caused by non-ophiostomatoid fungi have been recorded in South Africa. Examples include Arnylostereurn areolatum and A. chailletii vectored by the woodwasp, Sirex noctilio (Madden, 1988; Hurley et al. 2007). P. radiata is also associated with members of the Ophiostomatales that can cause sapstain (Reay et al. 2002). The mere ability of all species tested in this study to grow on this host may indicate that some native Ophiostomatales may well be of future economic importance if these prove to cause similar wood defects.

The wound-associated species $G$. roseus and $O$. pluriannulatum-like were pathogenic on several tree species. G. roseus was pathogenic on the non-native A. mearnsii and E. grandis as well as on the native $R$. melanophloes and $C$. dentata. This species was recently isolated from several native hosts, including Curtisia dentata, Halleria lucida, Pterocelastrus tricuspidatus, Trichocladus crinitus and O. capensis ssp. macrocarpa (Musvuugwa, 2014). Interestingly it is also associated with several wound-associated mites such as Oribatida sp. 2, Lasioseius sp. 1 and Mesostigmata sp. 1 (Musvuugwa, 2014). These mites may aid the transport of this fungus to many hosts, especially since these hosts grow in sympatry. Since it is possible that this fungus is vectored by its associated mites, it is likely that it can at some 
point be transported to these exotic hosts and pose a danger to South Africa's forestry industry. This scenario has occurred at least once before in South Africa, when C. albifundus shifted hosts from native taxa to the non-native $A$. mearnsii, causing a serious wilt disease that led to financial losses in the forestry industry (De Beer, 1994; Roux and Wingfield, 1997; Roux et al. 1999). Similarly, O. pluriannulatum-like is also known from many native hosts and the exotic A. mearnsii, and is also associated with several mite species (Musvuugwa, 2014). It has now been confirmed to be pathogenic to A. mearnsii and may therefore pose a significant threat should it move into plantation forestry areas. The current distribution of this fungus is unknown, but as A. mearnsii has invaded much of coastal South Africa, it may well be able to extend its range rapidly eastwards to where A. mearnsii is commercially planted. The other wound-associated fungus, S. rapaneae, was pathogenic on its host $R$. melanophloeos and on $C$. dentata. Currently the fungus is only known from $R$. melanophloeos and its associated arthropods are unknown. These arthropods are highly likely to be mites, as mites have been observed on $S$. rapaneae fungal mats under the bark of this tree (pers. observ.). We suspect that the vector species is probably rather specific to this host, as this fungus has thus far been only collected from this host tree, despite focussed collection effort (Musvuugwa, 2014).

Three of the fungal species from pine trees, associated with D. quadrisetus and $O$. erosus, were also pathogenic on some of the tree species tested. Although these fungi were able to grow on almost all the tree species they were tested on, they were only pathogenic on a few. Sporothrix sp. 1 was pathogenic on E. grandis, the Ceratocystiopsis species was pathogenic on $C$. dentata, and $O$. ips was pathogenic on E. grandis and $R$. melanophloeos. These species may be able to move to E. grandis and native hosts in areas where these occur in close proximity using $D$. quadrisetus as a carrier. This notion is aided by the recent collection of 
this mite from both native and exotic bark beetles and hosts (Musvuugwa, 2014). A possible reason why none of these fungi have been found on native hosts yet is that this mite has moved from pine-associated beetles to a beetle associated with $O$. capensis ssp. macrocarpa (Musvuugwa, 2014), a host that seems to be very resistant to attack by members of the Ophiostomatales. However, this beetle may not be very host specific as it is also known from Gonioma kamassi (Musvuugwa, 2014). Future exchanges of these fungi between usual and non-usual hosts therefore cannot be ruled out.

The beetle-associated fungi from native hosts, $S$. pallida and $R$. rapaneae, were able to grow on all tree species and were pathogenic on some. Both species were pathogenic on $C$. dentata, while $S$. pallida was also pathogenic on $R$. melanophloeos and $R$. rapaneae was also pathogenic on E. grandis. Sporothrix pallida is associated with two beetle species, Lanurgus sp. 1 and Ctonoxylon sp. 1, as well as with the phoretic mite of Lanurgus sp. 1 (D. quadrisetus) (Musvuugwa, 2014). The fact that this fungus is associated with three different arthropods may aid its dispersal to new hosts on which it may be pathogenic. In fact, this species may not be very vector specific at all, as it is known from many different environments (de Meyer et al. 2008). Conversely, $R$. rapaneae is currently only known as an associate of one Platypodinae beetle species and is likely ambrosial (Musvuugwa et al. 2015). It may therefore be highly specific to its beetle associate, which would reduce the chances of it being vectored to another host tree.

\section{Conclusions}

Even though efforts are made to restrict the movement of exotic species across the borders of countries, many Ophiostomatales species continuously invade new regions (e.g. Kubono and Ito, 2002; Brasier, 2008; Loo, 2009; Brasier and Webber, 2010). Preventing introductions 
especially in developing countries that are under pressure for increased growth in international trade, is therefore extremely difficult. This is due to the cryptic nature of the fungi and their vector organisms and a lack of appropriately experienced scientists to perform risk analyses (Plant Health (Phytosanitary) Policy for South Africa 2014). A shift in focus to mitigating the spread of exotic species within countries and the facilitation of their eradication and/or control is, therefore, often needed. For fungi in the Ophiostomatales, eradication and/or control are not attainable when these fungi enter natural ecosystems due to their close integration into these systems. Focus should, therefore, be on restricting movement of affected exotic plant materials (such as logs used for making fires) within countries to prevent these from coming in contact with indigenous ecosystems as much as possible. The eradication of exotic invasive species (e.g. Acacia mearnsii, Eucalyptus spp. and Pinus spp. in South Africa), many of which are hosts to both native and non-native Ophiostomatales (Musvuugwa, 2014), should also be targeted as these can act as conduits for the movement of associated exotic and indigenous organisms across the invaded ranges (Van der Colff et al. 2015). This should especially be prioritised in areas where these grow in close proximity to natural forests where indigenous and exotic hosts often occur in sympatry (Moran and Hoffman, 2012).

Many of the fungal species assessed in this study may threaten new hosts that they may encounter. This is especially true for those species found on wounds and those associated with several arthropod taxa. These threats are less likely for fungal species associated with sub-cortical beetles, unless newly encountered hosts are phylogenetically closely related to the usual hosts. The virulence of the pathogenic fungi identified here is not yet known, but some taxa may be able to kill newly encountered hosts. However, even if these cannot kill 
their hosts, they could still pose a great ecological (when exotic fungi compete with native fungi) or economic threat (e.g. blue staining of lumber).

\section{Acknowledgements}

The authors thank the DST/NRF Centre of Excellence in Tree Health Biotechnology (CHTB) for financial support and the South African National Parks Board (SANPARKS) and Western Cape Nature Conservation Board for issuing the necessary collecting permits. We are also grateful to Netsai Machingambi, PC Benade and Dewidine van der Colff for assistance with field work and Jane Forrester for permission to work on trees in the Harold Porter National Botanical Garden. Special thanks to Michail Mandelshtam for identification of the beetles and to Richard Hofstetter and John Moser for help in identification of mites. Lastly we also wish to thank Wilhelm Z. de Beer, Tuan Duong and Kenneth Oberlander for guidance and help in molecular techniques to identify fungi used in this study and two anonomous reviewers for helpful suggestions to improve earlier versions of this manuscript.

\section{References}

Brasier, C.M., 2008. The biosecurity threat to the UK and global environment from international trade in plants. Plant Pathol. 57, 792-808.

Brasier, C.M., 1990. China and the origins of Dutch elm disease: an appraisal. Plant Pathol. $39,5-16$.

Brasier, C., Webber, J., 2010. Sudden larch death. An aggressive and unpredictable fungal pathogen is devastating larch plantations in Britain. Its remarkably broad host range, and the possibility of further geographical spread, give heightened cause for concern. Nature 466, 824-825. 
Brasier, C.M., Buck, K.W., 2001. Rapid evolutionary changes in a globally invading fungal pathogen (Dutch elm disease). Biol. Invasions 3, 223-233.

Bridges, J.R., Moser, J.C., 1983. Role of two phoretic mites in transmission of bluestain fungus, Ceratocystis minor. Ecol. Entomol. 8, 9-12.

Cardoza, Y.J., Moser, J.C., Klepzig, K.D., Raffa, K.F., 2008. Multipartite symbioses among fungi, mites, nematodes, and the spruce beetle, Dendroctonus rufipennis. Environ. Entomol. 37, 956-963.

Chen, S.F., Wingfield, M.J., Roets, F., Roux, J., 2013. A serious canker caused by Immersiporthe knoxdaviesiana gen. et sp. nov. (Cryphonectriaceae) on native Rapanea melanophloeos in South Africa. Plant Pathol. 62, 667-678.

Cruywagen, E.M., de Beer, Z.W., Roux, J., Wingfield M.J., 2010. Three new Graphium species from baobab trees in South Africa and Madagascar. Persoonia 25, 61-71.

De Beer, C., 1994. Ceratocystis frimbiata with special reference to its occurrence as a pathogen on Acacia Mearnsii in South Africa. M.Sc. Thesis. University of the Orange Free State. Bloemfontein. South Africa, pp 42-88.

De Meyer, E.M., De Beer, Z.W., Summerbell, R.C., Moharram, A.M., De Hoog, G.S., Vismer, H.F., Wingfield, M.J., 2008. Taxonomy and phylogeny of new wood- and soilinhabiting Sporothrix species in the Ophiostoma stenoceras-Sporothrix schenckii complex. Mycologia 100, 647-661.

DiGuistinia, S., Wanga, Y., Liaob, N.L., Taylorb, G., Tanguayc, P., Feaud, N., Henrissate, B., Chanb, S.K., Hesse-Orcea, U., Alamoutia, S.M., Tsuif, C.K.M., Dockingb, R.T., Levasseurg, A., Haridasa, S., Robertsonb, G., Birolb, I., Holtb, R.A., Marrab, M.A., Hamelinc, R.C., Hirstb, M., Jonesb, S.J.M., Bohlmannf, J., Breuila, C., 2011. Genome and transcriptome analyses of the mountain pine beetle-fungal symbiont Grosmannia clavigera, a lodgepole pine pathogen. PNAS 108, 2504-2509. 
Hammerbacher, A., Schmidt, A., Wadke, N., Wright, L.P., Schneider, B., Bohlmann, J., Brand, W.A., Fenning, T.M., Gershenzon, J., Paetz, C., 2013. A Common Fungal Associate of the Spruce Bark Beetle Metabolizes the Stilbene Defenses of Norway Spruce. Plant Physiol. 162, 1324-1336.

Harrington, T.C., 2005. Ecology and evolution of mycophagous bark beetles and their fungal partners, in: Vega, F.E., Blackwell, M. (Eds.), Insect-Fungal Associations: Ecology and Evolution. Oxford University Press, New York, pp. 1-22.

Harrington, T.C., 1987. New combinations in Ophiostoma of Ceratocystis species with Leptographium anamorphs. Mycotaxon 28, 39-43.

Harrington, T.C., Fraedrich, S.W., Aghayeva, D.N., 2008. Raffaelea lauricola, a new ambrosia beetle symbiont and pathogen on the Lauraceae. Mycotaxon 104, 399-404.

Henriques, J., de Lurdes Inacio, M., Sousa, E., 2006. Ambrosia fungi in the insect-fungi symbiosis in relation to cork oak decline. Rev. Iberoam. Micol. 23, 185-188.

Heybroek, H.M., 1993. Why bother about the elm?, in: Sticklen, M.B., Sherald, J.L. (Eds.), Dutch Elm Disease Research. Cellular and Molecular Approaches. Springer-Verlag, New York, pp 1-8.

Hofstetter, R.W., Moser, J.C., Blomquist, S.R., 2013. Mites associated with bark beetles and their hyperphoretic Ophiostomatoid fungi, in: Seifert, K.A., De Beer, Z.W., Wingfield, M.J. (Eds.), Ophiostomatoid Fungi: Expanding Frontiers. CBS Biodiversity Series 12, 165-174. Hurley, B.P., Slippers B., Wingfield, M.I., 2007. A comparison of control results for the alien invasive woodwasp, Sirex noctilio, in the southern hemisphere. Agric. For. Entomol. 9, 159171. 
Jacobs, K, Bergdahl, D.R., Wingfield, M.J., Halik, S., Seifert, K.A, Bright, D.E., Wingfield, B.D. 2004. Leptographium wingfieldii introduced into North America and found associated with exotic Tomicus piniperda and native bark beetles. Mycol. Res. 108, 411-418.

Jacobs, K., Seifert, K.A., Harrison, K.J., Kirisits, T., 2003. Identity and phylogenetic relationships of ophiostomatoid fungi associated with invasive and native Tetropium spp. (Coleoptera: Cerambycidae) in Atlantic Canada. Can. J. Bot. 81, 316-29.

Jacobs, K., Wingfield, M.J., 2001. Leptographium species: Tree pathogens, insect associates, and agents of blue-stain. APS press, St Paul, Minnesota.

Kamgan Nkuekam, G., Jacobs, K., De Beer, Z.W., Wingfield, M.J., Roux, J., 2008. Ceratocystis and Ophiostoma species including three new taxa, associated with wounds on native South African trees. Fungal Divers. 29, 37-59.

Kinn, D.N., 1967. Notes on the life cycle and habitats of Digamasellus quadrisetus (Mesostigmata: Digamasellidae). Ann. Entomol. Soc. America 60, 862-865.

Klepzig, K.D., Six D.L., 2004. Bark beetle-fungal symbiosis: context dependency in complex associations. Symbiosis 37, 189-205.

Klepzig, K.D., Moser, J.C., Lombardero, M.J, Hofstetter, R.W., Ayres, M.P., 2001. Symbiosis and competition: Complex interactions among beetles, fungi and mites. Symbiosis $30,83-96$.

Kubono, T., Ito, S., 2002. Raffaelea quercivora sp. nov. associated with mass mortality of Japanese oak, and the ambrosia beetle (Platypus quercivorus ). Mycoscience 43, 255-260. Lamb, R .1979. World without Trees. Wildwood House, London. Lombardero, M.J., Ayres, M.P., Hofstetter, R.W., Moser, J.C., Klepzig, K.D., 2003. Strong indirect interactions of Tarsonemus mites (Acarina: Tarsonemidae) and Dendroctonus frontalis (Coleoptera: Scolytidae). Oikos 102, 243-252. 
Loo, J.A., 2009. Ecological impacts of non-indigenous invasive fungi as forest pathogens.

Biol. Invasions 11, 81-96.

Machingambi, N., Dreyer, 1., Oberlander, K.C., Roux, J., Roets, F., 2015. Death of endemic Virgilia oroboides trees in South Africa caused by Diaporthe virgiliae sp. nov. Plant Pathol. 64, 1149-1156.

Madden, J.L., 1988. Sirex in Australasia, in: Berryman, A.A. (Ed.), Dynamics of forest insect populations. Plenum Press, New York, pp. 407-429.

Malloch, D., Blackwell, M., 1993. Dispersal biology of the ophiostomatoid fungi, in: Wingfield, M.J., Seifert, K.A., Webber, J.F. (Eds.), Ceratocystis and Ophiostoma: Taxonomy, Ecology and Pathogenicity. APS Press, St. Paul, pp. 195-206.

Moran, V.C, Hoffmann, J.H., 2012. Conservation of the fynbos biome in the Cape Floral Region: the role of biological control in the management of invasive alien trees. BioControl 57, 139-149.

Morrison, A.S, Lockhart, S.R., Bromley, J.G., Kim, J.Y., Burd, E.M., 2013. An environmental Sporothrix as a cause of corneal ulcer. Med. Mycol. Case Rep. 2, 88-90.

Moser, J.C., 1985. Use of sporothecae by phoretic Tarsonemus mites to transport ascospores of coniferous bluestain fungi. Trans. Br. Mycol. Soc. 84, 750-753.

Moser, J.C., Perry, T.J., Bridges, J.R., Yin, H.-F., 1995. Ascospore dispersal of Ceratocystiopsis ranaculosus, a mycangial fungus of the southern pine beetle. Mycologia 87, 84-86.

Musvuugwa, T., 2014. Biodiversity and ecology of ophiostomatoid fungi associated with trees in the Cape Floristic Region of South Africa. PhD. Thesis. Stellenbosch University. South Africa.

Musvuugwa, T., de Beer, W.Z., Duong, T.A., Dreyer, L.L., Oberlander, K.C., Roets, F., 2015. New species of ophiostomatales from Scolytinae and Platypodinaebeetles in the Cape 
Floristic Region, including the discovery of the sexual state of Raffaelea. Antonie van Leeuwenhoek Journal of Microbiology. Accepted for publication

Paine, T.D., Raffa, K.F., Harrington, T.C., 1997. Interactions among Scolytid bark beetles, their associated fungi, and live host conifers. Ann. Rev. Entomol. 42, 179-206.

Peace, T., 1960. The status and development of elm disease in Britain. Forestry Commission Bulletin 33, 1-44.

Plant Health (Phytosanitary) Policy for South Africa 2014. General notice 889, Department of Agriculture, forestry and fisheries, volume 592, number 38102.

Price, T.S., Doggett, C., Pye, J.L., Holmes, T.P., 1992. A history of southern pine beetle outbreaks in the southeastern United States. Sponsored by the Souhtern Forest Insect Workshop Conference. The Georgia Forestry Commission, Macon, GA, pp. 65. Reay, S.D., Walsh, P.J., Ram, A., Farrell, R.L., 2002. The invasion of Pinus radiata seedlings by sapstain fungi, following attack by the Black Pine Bark Beetle, Hylastes ater (Coleoptera: Scolytidae). Forest Ecol. Manag. 165, 47-56.

Roets, F., Dreyer, L.L., Crous, P.W. and Wingfield, M.J. 2009. Mite-mediated hyperphoretic dispersal of Ophiostoma spp. from the infructescences of South African Protea spp. Environmental Entomology 38: 143-152.

Roets, F., Wingfield, M.J., Crous, P.W., Dreyer, L.L., 2007. Discovery of fungus-mite mutualism in a unique niche. Environ. Entomol. 36, 1226-1237.

Roux, J., Dunlop, R., Wingfield, M.J., 1999. Susceptibility of elite Acacia mearnsii families to Ceratocystis wilt in South Africa. J. For. Res. 4, 187-190.

Roux, J., Wingfield, M.J., 1997. Survey and virulence of fungi occurring on diseased Acacia Mearnsii in South Africa. Forest Ecol. Manag. 99, 327-336.

Six, D.L., 2003. Bark beetle-fungus symbioses, in: Bourtzis, K., Miller, T. (Eds.), Insect Symbioses. CRS press, Boca Raton, FL, pp. 97-114. 
Six, D.L., Wingfield, M.J., 2011. The role of phytopathogenicity in bark beetle-fungus symbioses: A challenge to the classic paradigm. Annu. Rev. Entomol. 56, 255-272.

Smiley, R.T., Moser, J.C., 1974. New Tarsonemids associated with bark beetles (Acarina: Tarsonemidae). Ann. Entomol. Soc. Am. 69, 713-715.

Van der Colff, D., Dreyer, L.L., Valentine, A., Roets, F., 2015. Invasive plant species may serve as a biological corridor for the invertebrate fauna of naturally isolated hosts. J. Insect Conserv. In press. DOI 10.1007/s10841-015-9804-3

Webber, J.F., 1990. The relative effectiveness of Scolytus scolytus, S. multistriatus and S. kirschii as vectors of Dutch elm disease. Eur. J. Forest Pathol. 20, 184-192.

Wingfield, M.J., 2003. Increasing threat of diseases to exotic plantation forests in the Southern Hemisphere: lessons from Cryphonectria canker. Australas. Plant Pathol. 32, 133139.

Walter, A.J., Venette, R.C., Kells, S.A., 2010. Acceptance and suitability of novel trees for Orthotomicus erosus, and exotic bark beetle in North America. Biol Invasions 12, 11331144.

Woolhouse, M.E.J., Haydon, D.T., Antia, R., 2005. Emerging pathogens: the epidemiology and evolution of species jumps. Trends Ecol. Evol. 20, 238-244. 